\title{
Implementasi Business Intelligence untuk Menganalisis Data Persalinan Anak di Klinik Ani Padang dengan Menggunakan Aplikasi Tableau Public
}

\author{
Ricky Akbar ${ }^{1}$, Azizi Soniawan ${ }^{2}$, Rafel Dinur ${ }^{3}$, Jovi Adrian ${ }^{4}$, Rafki Azim ${ }^{5}$, Afdhal Zikri ${ }^{6}$ \\ ${ }_{1,2,3,4,5,6}$ Program Studi Sistem Informasi, Fakultas Teknologi Informasi Universitas Andalas \\ 1afdhalzikr@gmail.com
}

\begin{abstract}
Abstrak-Pengelolaan data merupakan hal penting dari sebuah perusahaan namun prosesnya tidaklah mudah. Seiring dengan perkembangan teknologi, terciptalah banyak cara dalam mengolah dan mengatur data salah satunya yaitu Business intelligence (BI) yang merupakan sebuah proses untuk melakukan ekstrasi data-data operasional perusahaan dan mengumpulkannya dalam sebuah data warehouse. BI tidak hanya digunakan untuk perusahaan saja tetapi bisa diterapkan pada hal lainnya. Klinik Ani merupakan klinik yang telah berdiri sebelum tahun 2000. Klinik tersebut memiliki record data dari tiap pasien yang telah ditanganinya, salah satunya persalinan. Namun karena proses yang digunakan masih berbentuk manual, klinik tersebut masih belum bisa meningkatkan efektifitas dak efisiensinya sebaik mungkin. Penelitian ini bertujuan untuk memberikan informasiinformasi yang berguna untuk meningkatkan efektifitas dan efisiensi pada klinik tersebut dengan dasar Business intelligence. Dalam penelitian ini, analisis data dilakukan dengan menggunakan aplikasi Tableau Public. Tableau Public adalah perangkat lunak bisnis intelijen yang mudah untuk digunakan, terutama dalam hal membuat visualisasi data, analisis data, dan pelaporan. Dengan metodologi deskriptif yang didapatkan dari hasil observasi terhadap data yang ada, akan didapatkan sebuah output berupa informasi tentang tren kelahiran/persalinan anak dalam empat semester terakhir di Klinik Ani Padang Sumatera Barat. Adapun informasi yang didapat dari hasil analisis adalah sebagai berikut: dalam empat semester terakhir pada tahun 2015 sampai 2016, total kelahiran anak tertinggi terjadi pada semester 2 di tahun 2015, dengan total kelahiran sebanyak 88 anak. Sedangkan angka kelahiran terendah terjadi pada semester awal di tahun 2015 dengan total persalinan/kelahiran sebanyak 54 anak, dan berdasarkan waktu persalinannya, pada tahun 2015 dan 2016 kelahiran anak paling banyak terjadi pada waktu pagi hari.
\end{abstract}

Kata kunci-Business Intelligence, Data Warehouse, Tableau Public, Tren

\section{PENDAHULUAN}

Perkembangan teknologi informasi yang begitu pesat telah merambah ke berbagai sektor, termasuk sektor kesehatan. Teknologi informasi juga memiliki potensi dalam memproses data dan mengolahnya menjadi berbagai informasi. Selain itu teknologi informasi juga mampu menyimpan data dengan jumlah kapasitas jauh lebih banyak dari cara-cara manual.
Pemanfaatan teknologi komunikasi juga memungkinkan data dikirim secara mudah dan cepat.

Kecepatan pengolahan data dan pengambilan informasi yang akan dijadikan untuk pengambilan keputusan pada sebuah instansi atau organisasi, akan sangat menguntungkan dan memberi manfaat untuk organisasi/instansi tersebut. Informasi yang tepat dan akurat akan membuat instansi yang bersangkutan mampu menanggulangi dan menghindari kejadian atau peristiwa yang dapat mengakibatkan kerugian pada instansi tersebut.

Di instansi kesehatan seperti rumah sakit atau klinik, banyak sekali terdapat data-data yang terkait dengan bidang kesehatan. Data yang melimpah akan menjadi tidak berguna apabila tidak ada pengelolaan yang baik dan pemanfaatan yang optimal. Instansi pemerintah merasa kesulitan dalam mengelola data yang cukup besar bila menggunakan tools yang sangat sederhana yang tidak mampu menghasilkan informasi yang tepat dan mengakibatkan kekeliruan dalam pengambilan keputusan.

Klinik Ani Padang sebagai instansi kesehatan, setiap tahunnya juga mengeluarkan berbagai data-data terkait kesehatan, salah satunya data rekap persalinan per tahunnya. Namun data-data rekapitulasi yang ada belum bisa termanfaatkan secara optimal karena belum adanya pemanfaatan teknologi informasi dan penggunaan tools yang dapat membantu menghasilkan informasi dari data-data yang ada. Masalah pengolahan data menjadi informasi yang berguna ini dapat diselesaikan dengan Business Intelligence.

Business Intelligence (BI) merupakan salah satu bentuk implementasi teknologi informasi, yang mampu menjawab kebutuhan untuk menganalisis masalahmasalah serta dapat digunakan dalam pengambilan keputusan[1]. Secara ringkas, BI dapat diartikan sebagai pengetahuan yang didapatkan dari hasil analisis data yang diperoleh dari kegiatan suatu organisasi/instansi, termasuk instansi kesehatan seperti Klinik Ani Padang.

Pentingnya penggunaan Business Intelligence (BI) untuk instansi kesehatan seperti Klinik Ani Padang salah satunya adalah dapat digunakan untuk pengolahan data-data persalinan, seperti untuk mengetahui bagaimana tren jumlah kelahiran/persalinan setiap tahunnya. Dalam penelitian ini, variabel yang digunakan untuk mengetahui tren 
kelahiran tersebut adalah berdasarkan jenis kelamin anak dan waktu terjadinya persalinan. Informasi yang didapatkan dari hasil analisis ini nantinya diharapkan mampu membantu Klinik Ani dalam pengambilan keputusan yang tepat.

Adapun metodologi yang digunakan dalam penelitian ini adalah metodologi deskriptif yang dapat diperoleh dengan cara observasi. Metode analisis deskriptif merupakan metode penelitian dengan cara mengumpulkan data-data sesuai dengan yang sebenarnya kemudian data-data tersebut disusun, diolah dan dianalisis untuk dapat memberikan gambaran mengenai masalah yang ada. Adapun tools yang digunakan dalam penelitian ini adalah Tableau Public. Tableau adalah perangkat lunak bisnis intelijen yang mudah untuk digunakan, terutama dalam hal membuat visualisasi data, analisis data, dan pelaporan.

\section{LANDASAN TEORI}

\section{A. Business Intelligence (BI)}

Business Intelligence adalah suatu cara untuk mengumpulkan, menyimpan, mengorganisasikan, membentuk ulang, meringkas data serta menyediakan informasi, baik berupa data aktivitas bisnis internal perusahaan, maupun data aktivitas bisnis eksternal perusahaan termasuk aktivitas bisnis para pesaing yang mudah diakses serta dianalisis untuk berbagai kegiatan manajemen [2].

Business Intelligence merupakan sebuah proses untuk melakukan ekstraksi data-data operasional perusahaan dan mengumpulkannya dalam sebuah data warehouse. Selama proses ekstraksi juga dapat dilakukan transformasi dengan menerapkan berbagai formula, agregasi, maupun validasi sehingga didapat data yang sesuai dengan kepentingan analisis bisnis. Selanjutnya data di data warehouse diproses menggunakan berbagai analisis statistik dalam proses data mining, sehingga didapat berbagai kecenderungan atau pattern dari data. Hasil penyederhanaan dan peringkasan ini disajikan kepada end user yang biasanya merupakan pengambil keputusan bisnis. Dengan demikian manajemen dapat mengambil keputusan berdasarkan fakta-fakta aktual, dan tidak hanya mengandalkan intuisi dan pengalaman kuantitatif saja [3].

Business Intelligence menjelaskan tentang suatu konsep dan metode bagiamana untuk meningkatkan kualitas pengambilan keputusan bisnis berdasarkan sistem yang berbasiskan data. BI seringkali dipersamakan sebagaimana briefing books, report and query tools, dan sistem informasi eksekutif. BI merupakan sistem pendukung pengambilan keputusan yang berbasiskan data-data [4].

Business Intelligence adalah alat analisis yang digunakan untuk mengkonsolidasikan data, menganalisis, menyimpan dan mengakses banyak data untuk membantu dalam pembuatan keputusan, seperti perangkat lunak untuk query database dan pelaporan, alat untuk analisis data multidimensi, dan data mining [5].
Menurut Ronald (2008) ada beberapa bagian dalam solusi business intelligence yaitu, keseluruhan proses dalam business intelligence dapat diterjemahkan menjadi langkah-langkah dibawah ini [6] :

1. Identifikasi masalah bisnis yang perlu diselesaikan dengan gudang data dan menentukan data yang diperlukan untuk menyelesaikan masalah tersebut.

2. Identifikasi lokasi dari data-data yang diperlukan dan mengambilnya dari sumber penyimpanannya.

3. Merubah data yang diperoleh dari beragam sumber tersebut ke dalam sebuah data yang konsisten.

4. Mengambil data yang telah dirubah tersebut ke dalam lokasi yang yang tersentralisasi.

5. Membuat sebuah gudang data dengan data yang ada dalam lokasi yang tersentralisasi tersebut

6. Memasang sebuah produk atau aplikasi yang dapat memberikan akses ke data yang ada dalam cube tadi. Ada berbagai macam jalan dan cara untuk berbagai macam tipe pekerjaan ketika berurusan dengan cube.

\section{B. Tableau Public}

Tableau adalah perangkat lunak bisnis intelijen yang mudah untuk digunakan, terutama dalam hal membuat visualisasi data, analisis data, dan pelaporan. Cara penggunaannya cukup mudah karena mengunakan sistem drag and drop. Tableau dapat menggabungkan data dari berbagai sumber data seperti spreadsheet, database, cloud data, dan big data ke dalam satu program untuk digunakan dalam suatu analisis yang dinamis[7].

Ada beberapa manfaat menggunakan Tableau dibandingkan dengan Traditional BI tool lainnya, manfaat tersebut dapat dilihat pada tabel 1 berikut:

Tabel 1. Keunggulan tableau dibandingkan dengan metode tradisional[6]

\begin{tabular}{|c|c|}
\hline Traditional Method & Tableau \\
\hline Membutuhkan & membutuhkan \\
\hline $\begin{array}{l}\text { keahlian } \\
\text { programming yang } \\
\text { khusus }\end{array}$ & keahlian programming \\
\hline
\end{tabular}

Focus hanya pada Dapat mengkombinasikan satu tipe database berbagai jenis sumber data yang berbeda-beda, seperti spreedsheet, database, cloud data, dan big data

Memakan waktu Menghemat waktu 


\begin{tabular}{|c|c|}
\hline Traditional Method & Tableau \\
\hline $\begin{array}{l}\text { Pengambil keputusan } \\
\text { harus meminta ahli } \\
\text { IT } \\
\text { memperoleh } \\
\text { informasi } \\
\text { database }\end{array}$ & $\begin{array}{lr}\text { Pengambil keputusan } \\
\text { dapat secara langsung } \\
\text { menggunakan dashboard } \\
\text { untuk memperoleh } \\
\text { informasi }\end{array}$ \\
\hline $\begin{array}{l}\text { Sangat tergantung } \\
\text { pada bahasa query }\end{array}$ & $\begin{array}{l}\text { Query dijalankan dibalik } \\
\text { layar }\end{array}$ \\
\hline $\begin{array}{l}\text { Mengkombinasi } \\
\text { sumber data yang } \\
\text { berbeda sulit untuk } \\
\text { dilakukan }\end{array}$ & $\begin{array}{l}\text { Perbedaan sumberdata } \\
\text { dapat di kombinasikan } \\
\text { dengan mudah }\end{array}$ \\
\hline Relatif Mahal & Harga terjangkau \\
\hline $\begin{array}{l}\text { Banyak dirancang } \\
\text { untuk bisnis yang } \\
\text { besar }\end{array}$ & $\begin{array}{l}\text { Solusi BI yang sempurna } \\
\text { untuk bisnis yang kecil, } \\
\text { medium dan luas }\end{array}$ \\
\hline
\end{tabular}

\section{PEMBAHASAN DAN HASIL}

Pada bab ini akan diuraikaan bagaimana hasil penelitian serta pembahasan dari hasil penelitian, yaitu bagaimana hasil dari pengolahan data-data persalinan yang ada, sehingga nantinya didapati output berupa tren kelahiran anak pada empat semester terakhir di Klinik Ani Padang serta perbandingan jumlah anak yang lahir berdasarkan jenis kelaminnya pada emapat semester terakhir di Klinik Ani Padang.

\section{A. Langkah Pengolahan Data}

Data yang diambil dalam jurnal ini yaitu data persalinan anak di Klinik Ani Padang Sumatera Barat dari tahun 2015-2016. Data tersebut didapatkan langsung dari Klinik Ani Padang. Data yang didapatkan berbentuk data excel yang terdiri dari 293 rows dan 12 coulumn yang terdiri dari no, nama pasien, umur, nama suami, pekerjaan, alamat, hari/tgl, jam kelahiran, jenis kelamin anak, berat badan, panjang badan anak dan keterangan. Data yang ada kemudian akan dianalisis per semester, yang artinya ada 4 semester yang akan dianalisis pada penelitian ini.

\section{B. Proses Eksekusi Data}

Proses eksekusi dari data menggunakan Tableau Public yaitu :

1) Input/read data yang akan diproses, dimana data disini berupa data Excel. Tampilan Data Excel tersebut dapat dilihat pada Gambar 1.

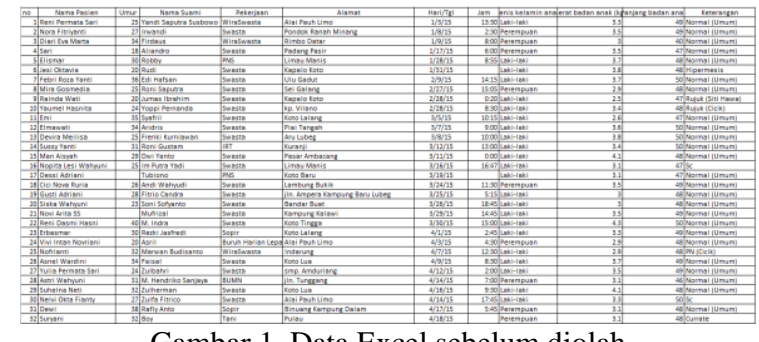

Gambar 1. Data Excel sebelum diolah

2) Kemudian lakukan koneksi data yang ada ke Tableau Public dengan cara drag file data ke aplikasi Tableau Public, data yang telah di drag sebelumnya akan menjadi data source untuk pengolahan nantinya. Data source yang akan dipakai dapat terlihat pada gambar 2 .

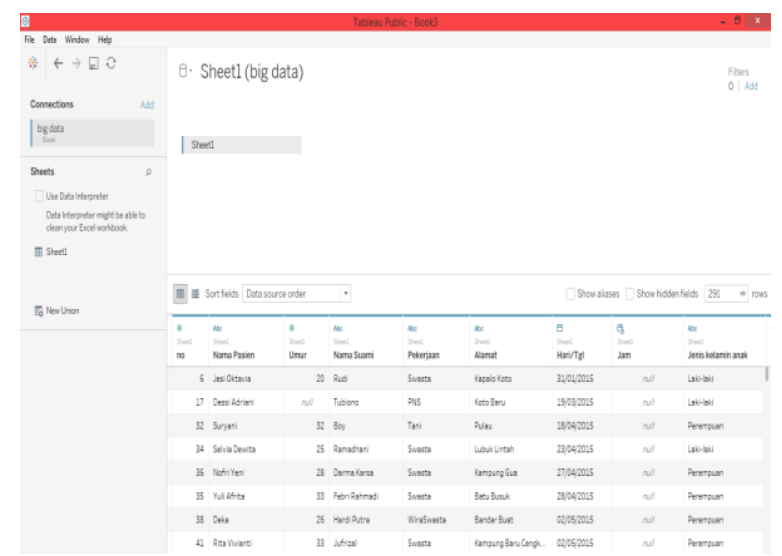

Gambar 2. Tampilan Data Source di Tableau Public

Dari gambar 2 di atas, dapat terlihat bahwa data excel yang akan digunakan telah terhubung ke Tableau Public.Selanjutnya akan muncul halaman worksheet yang akan digunakan untuk memfilter data persalinan anak di Klinik Ani Padang.

3) Selanjutnya dilakukan pengolahan dan analisis data berdasarkan variabel yang telah ditentukan, dalam hal ini variabel yang dipilih adalah jumlah kelahiran anak, jenis kelamin serta waktu kelahiran.

\section{Hasil Proses Data}

Dari hasil proses data yang dilakukan, didapatkan output berupa informasi perbandingan jumlah kelahiran berdasarkan jenis kelamin di Klinik Ani Padang pada empat semester terakhir yaitu tahun 2015 dan 2016, total jumlah persalinan serta waktu yang paling sering terjadinya persalinan di Klinik Ani Padang. Informasi yang didapatkan dapat dijadikan pedoman bagi Klinik Ani Padang dalam melakukan pengambilan keputusan.

Data perbandingan jumlah kelahiran berdasarkan jenis kelamin anak per bulan dapat dilihat pada gambar 3 dan 4 berikut ini. 


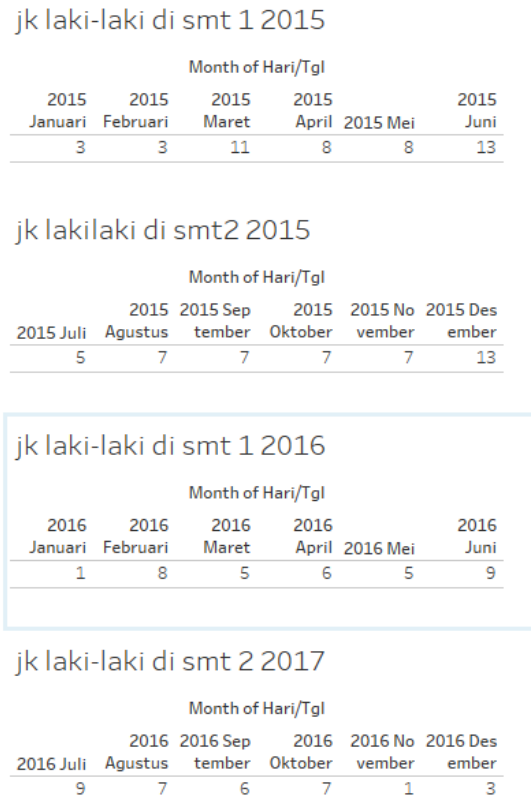

Gambar 3. Perbandingan jumlah kelahiran anak lakilaki per bulan

Dari gambar 3 di atas dapat dilihat jumlah kelahiran anak berjenis kelamin laki-laki di Klinik Ani pada setiap bulannya di tahun 2015 dan 2016. Sedangkan untuk jumlah kelahiran anak berjenis kelamin peremouan dapat dilihat pada gambar 4 berikut ini.
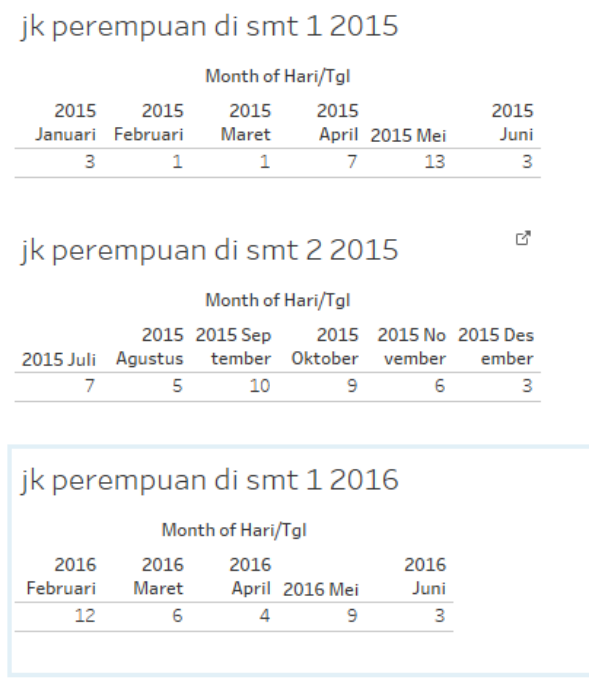

jk perempuan di smt 22016

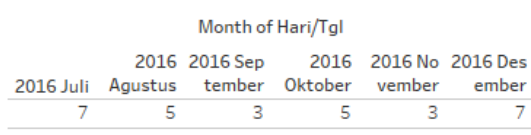

Gambar 4. Perbandingan jumlah kelahiran anak perempuan per bulan

Dari gambar 4 di atas dapat dilihat jumlah kelahiran anak berjenis kelamin perempuan di Klinik Ani pada setiap bulannya di tahun 2015 dan 2016.

Dari data jumlah kelahiran anak berdasarkan jenis kelamin tersebut, kemudian dilakukan analisis dengan menggunakan grafik dari hasil olahan aplikasi Tableau
Public. Grafik perbandingan jumlah kelahiran anak berdasarkan jenis kelaminnya dapat dilihat pada gambar 5 berikut.

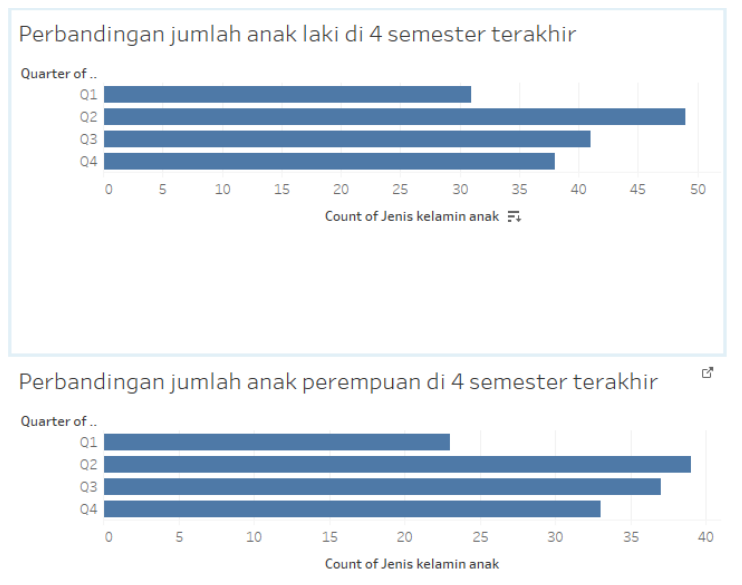

Gambar 5. Grafik perbandingan jumlah kelahiran berdasarkan jenis kelamin per semester

Dari gambar 5 di atas, didapatkan informasi bahwa kelahiran anak berjenis kelamin laki-laki paling tinggi terjadi pada semester 2 di tahun 2015 yaitu pada bulan juli sampai desember dengan jumlah kelahiran sebanyak 49 orang. Sedangkan untuk anak berjenis kelamin perempuan jumlah kelahiran paling tinggi juga terjadi pada semester 2 di tahun 2015 dengan jumlah kelahiran sebanyak 39 orang.

Sedangkan untuk total keseluruhan persalinan yang terjadi di Klinik Ani pada empat semester terakhir yaitu tahun 2015 dan 2016, dapat dilihat pada gambar 6 berikut.

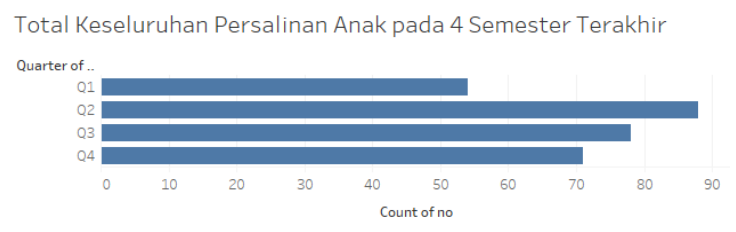

Gambar 6. Grafik perbandingan total jumlah kelahiran anak per semester

Berdasarkan gambar 6 tersebut, didapatkan informasi bahwa jumlah kelahiran anak tertinggi terjadi pada semester 2 di tahun 2015 dengan total kelahiran sebanyak 88 orang. Sedangkan untuk jumlah kelahiran/persalinan anak terendah terjadi pada semester awal di tahun 2015 dengan total kelahiran sebanyak 54 orang.

Selain melakukan pengolahan terhadap jumlah kelahiran anak di Klinik Ani, dalam penelitian ini juga dilakukan analisis untuk waktu yang sering terjadinya persalinan di Klinik Ani Padang dalam 2 tahun terakhir. Hasil perbandingan jumlah kelahiran/persalinan anak berdasarkan waktu tersebut dapat dilihat pada gambar 7 di bawah ini. 


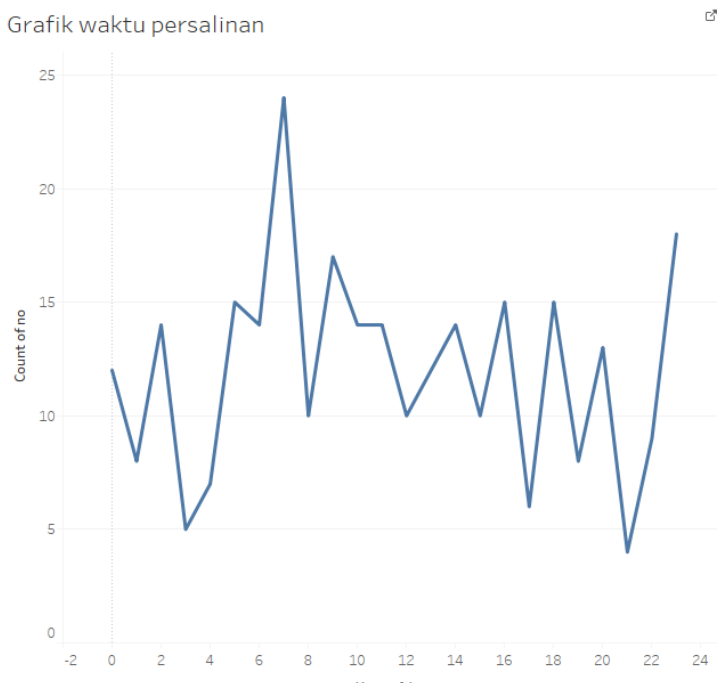

Gambar 7. Grafik jumlah persalinan berdasarkan waktu

Berdasarkan gambar 7 di atas, dapat disimpulkan bahwa jumlah persalinan anak tertinggi di Klinik Ani pada tahun 2015 dan 2016 terjadi pada pukul 07.00 WIB dengan total kelahiran anak sebanyak 24 orang dan jumlah kelahiran anak terendah terjadi pada pukul 21.00 dengan total kelahiran sebanyak 4 anak.

\section{KESIMPULAN}

Analisis data persalinan ini dilakukan untuk melihat bagaimana tren kelahiran/persalinan anak di Klinik Ani Padang pada empat semester terakhir yaitu di tahun 2015 dan 2016. Dari penelitian yang telah dilakukan jumlah kelahiran dihitung berdasarkan jenis kelamin dan waktu terjadinya persalinan. Informasi yang didapatkan dari penelitian ini dapat digunakan oleh Klinik Ani Padang sebagai pedoman dalam pengambilan keputusan terutama dalam peningkatan nilai bisnis di Klinik Ani sendiri.

Berdasarkan keseluruhan hasil penelitian yang telah dilakukan dengan menggunakan aplikasi Tableau Public, dapat diperoleh kesimpulan sebagai berikut:

1. Jumlah kelahiran anak berjenis kelamin lakilaki terbanyak terjadi pada bulan Juli sampai Desember di tahun 2015 yaitu sebanyak 49 anak.

2. Jumlah kelahiran anak berjenis kelamin perempuan terbanyak terjadi pada bulan Juli sampai Desember di tahun 2015 dengan jumlah kelahiran sebanyak 39 anak.

3. Jumlah persalinan anak yang terjadi di Klinik Ani pada tahun 2015 dan 2016 paling banyak terjadi pada pagi hari pukul 07.00 WIB.

4. Dalam empat semester terakhir pada tahun 2015 sampai 2016, total kelahiran anak tertinggi terjadi pada semester 2 di tahun 2015, dengan total kelahiran sebanyak 88 anak. Sedangkan angka kelahiran terendah terjadi pada semester awak di tahun 2015 dengan total persalinan/kelahiran sebanyak 54 anak.

\section{REFERENSI}

[1] Turban, et al. (2004). Electronic Commerce : A Managerial Perspective.Prentice Hall. New Jersey

[2] David, Edward. 2000. "Business Intelligence, Have We Forgotten the Basics", white paper from www.bitpipe.com.

[3] Imelda, S.T, M.T. 2013. Business Intellegence. 111122

[4] Power, D.J. 2002, "Decision support systems: Concepts and resources for managers". United State of America: Green Wood Publishing Group.

[5] Laudon, Kenneth C, Jane P. 2008, "Essen-tials of Business Information Sys-tems. 7th Edition". Pearson Prentice Hall.

[6] Rajagukguk, Ronald. 2008. (e-book) "Quick Intro to Microsoft Office PerformancePoint Server 2007”. ITB Bandung: MIC.

[7] Pengertian Tableau. http://Tableau.com diakses 26 April 2017 Sugiarto. 2002. "Ekonomi Mikro Sebuah Kajian Komprehensif". PT. Gramedia Pustaka Utama: Jakarta 